\title{
What to pay for nuclear power?
}

A House of Commons committee has thrown new light on the ways in which British governments too often make bad decisions, especially where technical matters are concerned.

Poor (in both senses) Britain is paying a heavy price for the incompetence of its public administration, especially of technical matters. That is the chief message of the splendid report from the House of Commons Select Committee on Energy published last week (see also page 7). Ostensibly, the committee set out to tell why the nationalized electricity utility in England and Wales called the Central Electricity Generating Board (CEGB) should have told a public inquiry in 1987 that the price of electricity from a newly constructed pressurized water reactor (PWR) would be 3.09 pence per kilowatt-hour, and should have been quoting prices more than twice as much when negotiating with the government the terms on which it should be privatized. Readers of the report will not be better able to name a figure for the cost of nuclear electricity, but they will have a better understanding of the vacillations of government policy on nuclear energy.

It is a bizarre tale. Since 1972, the CEGB has been seeking to build PWRs, on the grounds that they could be built more quickly and would be intrinsically more economical than the gas-cooled reactors it had inherited from Britain's earlier flirtation with nuclear power. In 1979, the incoming Conservative government said it would sanction a programme to build ten PWRs over some forthcoming decade, but was then constrained by its predecessor's decision that none would be built until there had been a public inquiry. By the time the construction of the first reactor had begun in 1987, the government had also decided that the electricity industry should be "privatized". But it failed to appreciate that its nuclear policy and privatization policy might be in conflict. Now there is a gigantic muddle.

What the energy committee has most usefully done is to throw light on the casual ways in which these policies were made. The plans to privatize the electricity industry were made public in February 1988 by the then Secretary of State for Energy, Mr Cecil Parkinson, without a serious attempt to tell whether they were feasible. On the generating side, CEGB was to be split into two parts, 'Big G' and 'Little G' (now National Power and PowerGen respectively), but in the face of the CEGB's protests that nuclear power would be a problem.

So it has proved to be. First, in July last year, the government was forced to concede that the older gascooled reactors would have to remain in public ownership: reactors nearing the ends of their lives, but saddled with huge liabilities for decommissioning, would hardly have been an attractive investment. But then, last November, it had to go the whole hog, and lump all nuclear generating capacity into a third company, called Nuclear Electric, that will remain in public ownership.

The fascinating argument between the CEGB and the government, now revealed, about the price of nuclear electricity has been a proxy for the Department of Energy's failure to understand what privatization would entail. Should the discount rate (the notional cost of money) be 8 or 10 per cent? Is it surprising that CEGB, when told to ask British Nuclear Fuels (ironically, publicly owned) for a fixed price for reprocessing fuel, should be quoted a price 30 per cent greater than expected? Or that the CEGB should want to amortize new reactors over 20 years (rather than the full 40 years of life expected) to allow, in part, for the political risks ahead? In the end, the government took the view that the CEGB was asking for too much, and said no.

This sorry sequence of events may have permanently queered the pitch for nuclear power in Britain, and will also have played havoc with the public accounts. Nuclear Electric will operate existing reactors with the help of a subsidy collected from electricity consumers and called a Fossil Fuel Levy. (Britain will thus be the first industrialized country to have a carbon tax.) The Energy Committee is right to demand that the fixing of this charge should be transparent. Further nuclear construction has been postponed until a review in 1994. The Energy Committee is right to insist that the outcome of that review should be publicly debated before future policy is made. Meanwhile, there is a PWR half-built in Suffolk whose future is uncertain; why not finish the plant but not load it with fuel? That would avoid decommissioning costs and provide a lasting monument to four decades of mismanagement.

\section{Hubble trouble}

The defects that have come to light in the Hubble Telescope are a serious setback for research.

There was always a risk that the Hubble Telescope, already more than three years late, would have been lost during the tricky process of putting it into orbit. That it should turn out to be incapable of being focused 